
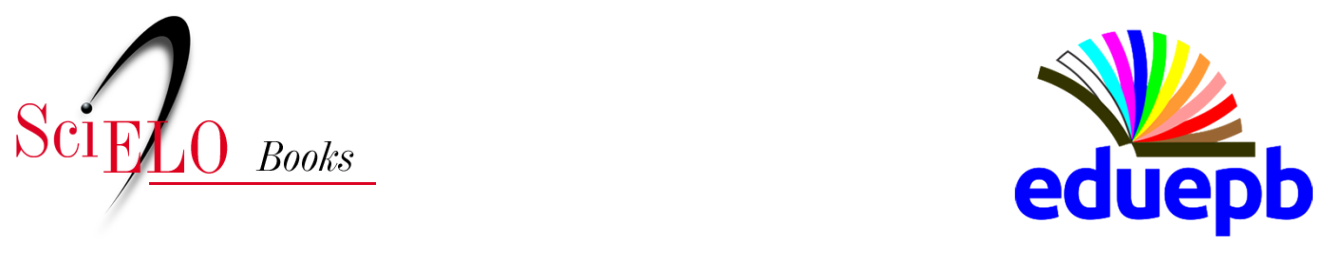

\title{
Utopias furtadianas \\ Carlos Lessa - Celso Furtado e a história da periferia mundial
}

\author{
Cidoval Morais de Sousa \\ Ivo Marcos Theis \\ José Luciano Albino Barbosa \\ (orgs.)
}

\section{SciELO Books / SciELO Livros / SciELO Libros}

SOUSA, C. M., THEIS, I. M., and BARBOSA, J. L. A., eds. Carlos Lessa Celso Furtado e a história da periferia mundial. In: Celso Furtado: a esperança militante (Depoimentos): vol. 2 [online]. Campina Grande: EDUEPB, 2020, pp. 378-392. Projeto editorial 100 anos de Celso Furtado collection. ISBN: 978-65-86221-11-4. https://doi.org/10.7476/9786586221671.0020.

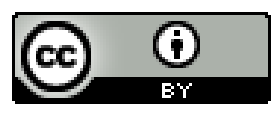

All the contents of this work, except where otherwise noted, is licensed under a Creative Commons Attribution 4.0 International license.

Todo o conteúdo deste trabalho, exceto quando houver ressalva, é publicado sob a licença Creative Commons Atribição 4.0.

Todo el contenido de esta obra, excepto donde se indique lo contrario, está bajo licencia de la licencia Creative Commons Reconocimento 4.0. 


\section{Carlos Lessa}
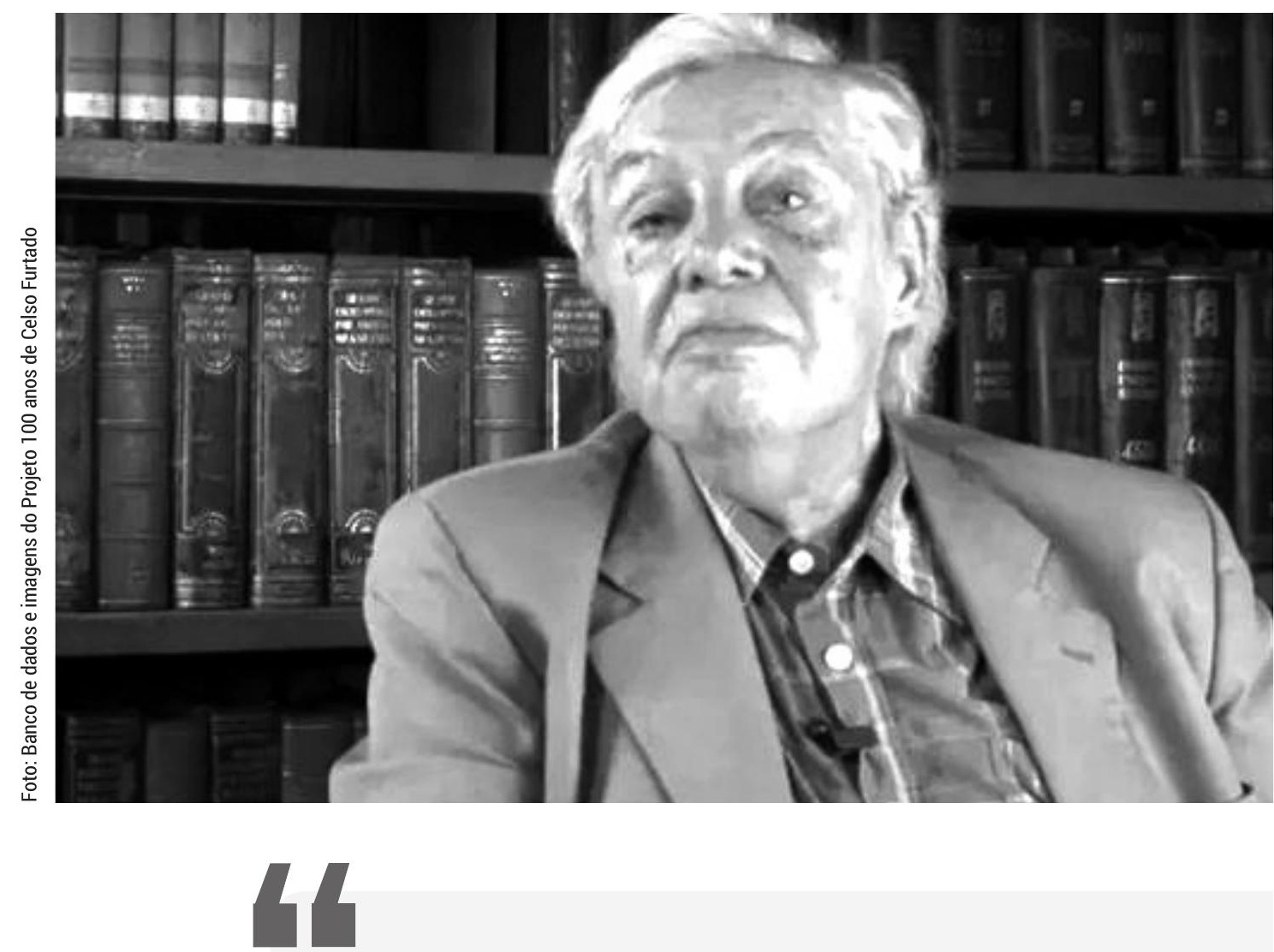

Certamente ninguém espera que haja, pelo neoliberalismo, uma abertura do mercado de trabalho mundial aos nossos excedentes de força de trabalho, nem que se faça qualquer sugestão, mesmo remota, de que o investimento do exterior é que irá dinamizar espontaneamente a periferia. Não é por aí. É pela nação ou não é pela nação. 0 que me angustia é que a nação está sendo desconstruída, e, ao mesmo tempo, no plano cultural, a ideia da república vai sendo devastada, porque o espaço da mercadoria vai atravessando, cada vez mais, os níveis que antes eram imaginados como níveis e espaços reservados à república. 


\section{Celso Furtado e a história da periferia mundial}

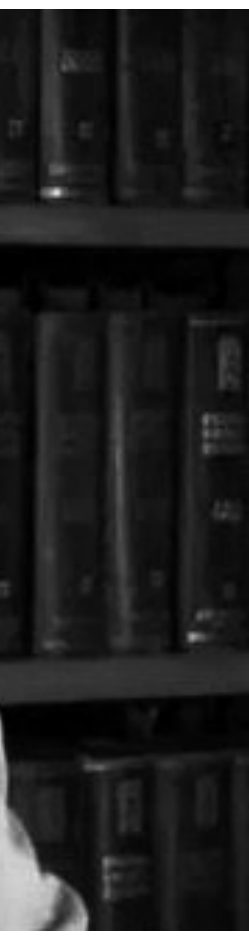

Peconomista carioca Carlos Lessa $\left(1936\right.$ - 2020) ${ }^{1}$ costumava dizer que Celso Furtado foi, para ele, a sua descoberta de Brasil. Filho de historiador, orgulhava-se de sua boa formação doméstica em história brasileira. Porém, ao ingressar na faculdade de economia na antiga Universidade do Brasil (hoje UFRJ), o Brasil "praticamente desapareceu de pauta”. Lembra, em uma de suas muitas entrevistas que, acompanhado de um grupo de colegas estudantes, procurou um famoso economista da época (se recusa a citar o nome) e perguntou-lhe qual era o maior problema do Brasil. A resposta veio dura e seca: só existe um - a inflação. Não havia, no curso de economia daquela época (final dos anos 1950), referências à economia brasileira e nem mesmo a seus problemas. Foi aí que, já bem perto de se graduar, encontrou numa livraria um livro de capa vermelha com o título de Formação Econômica do Brasil, de autoria de Celso Furtado, publicado pela Editora Fundo de Cultura, em primeira edição. Não teve dúvidas: comprou. "De repente um monte de informações que até então estavam espalhadas começaram a encontrar lugar e a fazer sentido", relembra.

O impacto da obra sobre a formação de Lessa, como ele mesmo sinaliza, foi incomensurável, "um raio de luz" em sua vida (EARP, 2010). Do grupo inicial de fundadores da Cepal, Furtado foi aquele que, segundo Lessa, deu "o salto de interrogação mais ambicioso depois da interrogação inicial”. Ora, se a interrogação inicial era como explicar a periferia subdesenvolvida do mundo, Furtado inovou refletindo sobre a dinâmica interna de cada país. Se os pioneiros da Cepal levaram a reflexão sobre a dialética centro-periferia às últimas consequências, Furtado foi além:

1 Economista, mestre em Análise Econômica pelo Conselho Nacional de Economia, doutorou-se em Ciências Humanas, em 1980, na Unicamp. Trabalhou em diferentes instituições: Centro Interamericano de Capacitação em Administração Pública (Cicap/ Venezuela), Universidade do Chile, Fundação Getúlio Vargas (FGV), Fundação para o Desenvolvimento da Administração Pública (Fundap), Unicamp, Conselho Superior de Previdência Social (CSPS), Universidade só Estado do Rio de Janeiro (Uerj), ainda serviu como assessor do ex-presidente do PMDB Ulysses Guimarães e dirigiu a área social do BNDES, o Finsocial (1985-1989). 
mergulhou o olhar para dentro da experiência histórica brasileira (e de países como Argentina, Venezuela e México), absorvendo, na compreensão de Lessa, a história da periferia mundial. Influenciado por essa leitura, Lessa foi em direção às ideias da Cepal, que serviram de reforço crítico em relação à economia política: a noção de centro e periferia como um pilar para o entendimento da situação do Brasil e aceitou a industrialização como condição estrutural para a superação da pobreza e da miséria (EARP, 2010).

Como professor, função que exerceu por quase toda a vida entre passagens por cargos públicos, foi eleito em 2002 reitor da Universidade Federal do Rio de Janeiro (UFRJ). Exerceu a presidência do BNDES entre 2003 e 2004, durante o governo Lula e acumulou passagens por diversas instituições, como: Ministério das Relações Exteriores, Comissão Econômica para a América Latina e o Caribe (Cepal/ONU), Superintendência de Desenvolvimento do Nordeste (Sudene), Banco Interamericano de Desenvolvimento (BID). Lessa também foi economista do Instituto Latinoamericano y del Caribe de Planificación Económica y Social (Ilpes/ONU) e consultor da Fundação para o Desenvolvimento da Administração Pública de São Paulo. Escreveu diversos livros sobre economia, entre eles Introdução à economia: uma abordagem estruturalista, sua obra mais conhecida, em parceria com Antônio Barros de Castro; O conceito de política econômica: Ciência e/ ou ideologia?; A estratégia de desenvolvimento 1974-1976 - Sonho e fracasso; e O Rio de todos os Brasis. Seu último livro foi Enciclopédia da brasilidade: Autoestima em verde-amarelo (2005), com textos sobre a história do país e suas festas populares. Dentre os temas recorrentes em sua produção tecnocientífica destaca-se a análise das políticas econômicas do Brasil, com especial atenção para o processo de industrialização e desenvolvimento.

O depoimento que reproduzimos a seguir foi apresentado em seminário organizado pelo Centro Internacional Celso Furtado, que teve como objetivo, de um lado, repensar o desenvolvimento, depois de mais de duas décadas de prevalência do ideário neoliberal, que escamoteou os problemas estruturais e impediu estratégias e políticas de superação do subdesenvolvimento; e, de outro, retomar as ideias do economista paraibano para, a partir delas, oferecer uma contribuição intelectual indispensável para que se refaçam diagnósticos e se formulem agendas públicas de uma economia política transformadora. Carlos Lessa faleceu no dia 5 de maio de 2020. Na homenagem que prestou a Celso Furtado 
reside também a nossa ao próprio Lessa, por tudo que ele representou para a interpretação e transformação do Brasil contemporâneo.

(Os organizadores)

\section{Depoimento}

- Estar aqui neste momento tem para mim um significado especial, ao olhar os que estão reunidos, ao ver as pessoas cujos caminhos tantas vezes se cruzaram com os nossos. E o motivo que nos reúne é prestar uma homenagem substantiva a Celso Furtado. Estive pensando em como fazê-lo e confesso que pensei em várias alternativas. E vou assumir uma que é, à primeira vista, menos rigorosa, mas tem para mim um conteúdo importante. Aprendi com Furtado muitas coisas. Em primeiro lugar, seu livro Formação Econômica do Brasil foi o andaime pelo qual comecei a pensar o Brasil. Na verdade, creio que eu e a minha geração toda, pelo Formação Econômica do Brasil, foi levada a pensar o chamado "desenvolvimento enquanto processo histórico" e, ao mesmo tempo, a perceber que o puro discurso teórico, isolado da observação da história como grande parteira, era pouco fecundo. Nunca pude deixar de lado a minha enorme e imensa admiração, a dívida intelectual que tenho com o Formação Econômica do Brasil, livro em que esbarrei já quase terminando o curso de formação universitária. Contudo, houve outra dimensão de Furtado também extremamente importante na minha trajetória, que foi o conceito de subdesenvolvimento. E o conceito de subdesenvolvimento não é um conceito que congela, mas mostra como padrões históricos peculiares a determinadas organizações do espaço-mundo podem fazer com que certos países se modifiquem mas mantenham características estruturais intransformadas.

- Quase que parafraseando Lampedusa, tudo se modifica com muita rapidez, porém não sai do lugar. Quero então prestar uma homenagem ao mestre Furtado dizendo que, ao observar esse último quarto de século brasileiro, as duas lições principais que obtive da convivência com sua obra, logo no começo de minha trajetória de formação intelectual, continuam sendo extremamente importantes, presentes. 
É inquestionável que, nesses 25 anos, o Brasil teve, na melhor das hipóteses, um lento crescimento. Não vou falar de estagnação, porque essa é uma palavra que me cria uma série de problemas, já que interrompe processos, congela estados. Na verdade, houve lento crescimento. Porém, eu queria chamar a atenção para o fato de que houve intensas transformações por baixo desse lento crescimento, as quais se deram menos no espaço da economia e mais no chamado corpo social, político e institucional. Quero mostrar algumas delas e os elementos de perplexidade que nos colocam.

- A primeira é sobre algo que tem hoje aparentemente um peso cada vez menor dentro do chamado corpo social brasileiro: o setor agrícola. Aí é inquestionável, observando esse último quarto de século, que houve um espantoso desenvolvimento da empresa agrícola. O Brasil é hoje o quarto produtor mundial de grãos, o que é um desempenho, do ponto de vista quantitativo, extremamente expressivo. Essa agricultura, que deu origem a uma empresa extremamente moderna, que lança mão de tecnologias muito sofisticadas, convive com outras formas de produção que sugerem a não-transformação. Então, o mesmo país que é o quarto produtor de grãos, ainda tem no agro hoje dez milhões de brasileiros que estão rigorosamente na linha da miséria, com renda familiar igual ou inferior a um quarto de salário mínimo. Esses dez milhões correspondem mais ou menos aos brasileiros que não estão ligados à rede elétrica. Apesar de todo o esforço feito nesses anos, ainda temos uma percentagem relativamente expressiva de população, e certamente muito expressiva no campo, que ainda está no século XVIII, submetida ao biorritmo das galinhas no seu ciclo vital: dorme e acorda com as galinhas e com o cantar do galo, o que, por sinal, é muito simpático. Esse campo passou por algumas transformações que são, de certa maneira, inéditas e inquietantes.

- Alguém poderia dizer que o Brasil é cada vez mais uma plataforma de exportação de commodities e cada vez mais deposita seu medíocre crescimento no desempenho do setor agroexportador, e estaria assim reeditando algo da República Velha. É um engano, porque se cotejarmos o café com a soja, e vou me permitir fazer rapidamente um cotejo, perceberemos uma diferença muito importante. O café, na República Velha, era certamente produzido por "empresas e empresários brasileiros”, os fazendeiros de café. Era certamente transportado em 
ferrovias que haviam sido incorporadas pelos mesmos fazendeiros de café ou feitas pelo Estado a serviço da cafeicultura. Os exportadores eram brasileiros, eram grandes firmas brasileiras. E os bancos financiadores do café eram nacionais. A semente era produzida no país e o seu aperfeiçoamento genético era feito pelo Instituto Agronômico de Campinas, que desenvolvia novas variedades. Na verdade, todo o ciclo do café estava sob comando de interesses nacionais. Se eu fizer com a soja o mesmo exercício, o quadro é radicalmente diferente. Certamente as grandes empresas agrícolas são predominantemente nacionais, quase não há presença de empresas estrangeiras na produção de grãos. E o transporte, pelo menos na etapa do caminhão, ainda é feito por transportadoras nacionais, mas parou por aí, porque a semente não é mais brasileira, está controlada pela Monsanto, a exportação não é brasileira. Toda soja é comercializada por quatro empresas, nenhuma brasileira. O fertilizante não é mais brasileiro, é produzido por subsidiárias e filiais estrangeiras. Poderia ser nacional, mas foi privatizado o setor produtor de fertilizantes.

- O aperfeiçoamento técnico das variedades de soja não é mais da Embrapa, que está sendo sucateada; é, na verdade, alguma coisa que está no espaço - eu diria, no caso da soja - da Monsanto. E o maquinário também é todo produzido por filiais estrangeiras. Na cadeia produtiva da soja, ficou circunscrita ao Brasil apenas a etapa da produção. A sua articulação não se dá mais basicamente via bancos nacionais, e sim por meio de operações muito complexas, em que a Bolsa de Mercadorias e Futuros de Chicago é um elemento decisivo para a construção das cadeias que financiam o setor, a partir das quatro grandes operadoras desse mercado. É outra coisa, não é o café. Eu diria que talvez o ciclo da carne ainda se aproxima um pouco do café. Mas quanto à agroindústria açucareira, há sinais muito claros de que ela passa a ser, cada vez mais, objeto de uma atenção preferencial das empresas internacionais. Quero apenas chamar a atenção para o fato de que, frente a uma grande contração das commodities, não se espere uma reação igual à de 1929, porque os protagonistas são outros - já não são mais nacionais. Se eu passasse para a cidade brasileira, diria que a urbanização avançou muitíssimo neste país. Nós hoje formalmente temos $80 \%$ da população nas cidades. Acho que essa é uma variação um pouco excessiva, porque talvez a pequena cidade do interior, a pequeníssima cidade ainda tenha muito mais características de 
comunidade rural do que propriamente urbana, mas a maioria da população está urbanizada, e pelo menos metade da população está nas metrópoles. Essa metade das metrópoles reproduziu, interna corpores, as mesmas distâncias que existiam antes no espaço Brasil como um todo. É como se houvesse uma condensação das distâncias, agora justapostas dentro do espaço urbano, onde são marcadas impressionantes diferenças. Algumas dessas diferenças têm implicações no tecido social que creio não foram ainda adequadamente pensadas. Vou me permitir chamar a atenção para o seguinte aspecto: o homem urbano brasileiro hoje não é mais um migrante; ele é geralmente o filho de um migrante. Já não é mais da primeira geração que se transferiu para a cidade, em busca das luzes das cidades. Ele nasceu e se criou na cidade. Isso faz uma enorme diferença, porque o seu pai teve a percepção de sair do século XVIII e chegar ao século XX. Na verdade, a cidade aparecia ao migrante como um espaço cheio de possibilidades, alguma coisa como uma loteria da vida. Ele poderia dar sorte. Já o filho dele, aquele que nasceu na cidade, conhece o que a cidade pode oferecer e não tem mais nenhuma visão de espaço lotérico. Na verdade, ele recebe, a partir de um quarto de século de lento crescimento, a informação contrária: a de que a cidade não vai lhe dar nenhum bilhete. Então, encontra duas saídas possíveis. Uma delas é a tendência a uma neo-religiosidade. É um fenômeno absolutamente impressionante a velocidade com que isso progrediu. Eu até penso que, para a base recrutada pelas novas religiões, há um tipo de mobilidade transcendental, que seria a passagem para a afirmação em outro espaço. Mas há também uma mobilidade vertical, porque forma a sua própria hierarquia. Os pastores representam formas de ascenso social dentro dessa nova configuração. E são um protagonista absolutamente novo dentro do tecido social e político brasileiro. Não tenho informação muito atualizada do que está acontecendo nos países-irmãos do continente. Creio que o fenômeno é rigorosamente generalizado, está acontecendo em praticamente todas as capitais sul -americanas, em todas em metrópoles do nosso continente. Esse é um movimento extremamente inovador e que porta algumas questões desafiantes. Uma delas é a seguinte: será esse novo protagonista o fundador de uma nova ética? Será um protagonista relevante na trajetória política subsequente ou terá um outro tipo de comportamento? Não sei prognosticar, mas certamente esse é um dado fundamental se se quiser pensar mais além do já e do agora. Não tenho a menor 
dúvida de que Furtado em algum momento iria colocar dentro da cultura a que fazia referência o Octavio, essa construção de novos valores. Por favor, não façam nenhuma transposição weberiana para interpretar o fenômeno, porque não serve, é de outra natureza. Aqui não se dá origem a capitalismo nenhum, mas a outra coisa. Suponho inclusive que é uma reconstrução do tecido social, com a constituição de códigos próprios, regras próprias, uma espécie de construção cidadã, alternativa e paralela. Há um outro caminho, que nos coloca questões desafiantes. Vou me permitir fazer referência a duas delas. Primeiro, a família uniparental, que poderia ser tecnicamente a família onde existe o adulto e as crianças, mas um adulto apenas. Na visão de um movimento feminista, isso poderia ser uma afirmação, uma equiparação da mulher com o homem e uma plenitude de realização dela. Isso pode ser verdadeiro para setores médios da sociedade. Mas popularmente é uma tragédia, porque o perfil dessa família uniparental corresponde ao de uma mulher jovem, que tem um ou dois filhos de pais que não assumem a paternidade. Na verdade, ela não tem sequer o registro do pai. Essa mulher, como podem compreender, tem um problema duplo: obtenção de renda monetária e, ao mesmo tempo, guarda e proteção de sua criança. Obviamente é uma tarefa gigantesca para ela, que é presa fácil das firmas de terceirização informais. Uma das coisas mais indecentes que acontece na sociedade brasileira é que essas empresas que contratam a mão-de-obra para atividades-meio, que as grandes empresas terceirizaram, se nutrem basicamente dessa força de trabalho, pagando-lhe de forma aviltada. Sabem quantas são as famílias uniparentais desse tipo na cidade do Rio de Janeiro? Vinte por cento. Vinte por cento das famílias já são desse tipo. Por que isso está acontecendo? Creio que por muitas razões, mas o Pochmann podia imediatamente nos dar a resposta. A taxa de desemprego selvagem que assalta a juventude, na faixa que vai de 16 a 24 anos, chega a $47 \%$, sem ensino profissionalizante e sem perspectiva de inserção em qualquer atividade. É evidente que nenhum reprodutor vai assumir a paternidade de nenhum rebento. A pobre mãe assume porque o útero retém dentro de si o resultado de algum pequeno equívoco. Agora eu queria que projetassem um pouco além do que serão, no futuro do tecido social, os filhos dessas famílias. O que estamos criando em nosso corpo social? Um tipo de "casta", um estamento, uma espécie de resíduo social? É muito grave, é gravíssimo. Até onde eu consigo perceber, esse fenômeno é hoje 
dominante nas grandes cidades brasileiras. Não sei como se passa em outros países do continente, mas é um fenômeno de imensa e definitiva importância. Os jovens, tirando aqueles que se orientam pela ascendência para buscar realização em outro espaço, não têm alternativas. Então, obviamente, parte deles é atraída para o tráfico de drogas, em que a esperança de vida se resume a três ou quatro anos. É tão significativa a quantidade de mortes de jovens da pobreza nesse processo que a nossa pirâmide demográfica já está afetada pela falta de elementos masculinos com idade entre 16 e trinta anos. E nós ostentamos agora o duvidoso título de ter a quarta taxa de homicídios como causa de morte externa da população de 16 a 45 anos. Somos superados apenas pela África do Sul, pela Colômbia e pela Venezuela, e acredito que a maior parte dos países não tem estatística confiável para isso. Mas estamos no quarto lugar. Talvez um país da África subsaariana tenha taxas mais altas, mas não há registro. Dos países que registram, estamos em quarto lugar.

- Senhores, a juventude mantida dentro do espaço urbano, sem qualquer perspectiva de amanhã, sem visão de futuro, vivendo este tipo de processo a que me refiro, promete um cenário que, com o continuado e lento crescimento, não sei exatamente em que vai dar, mas não ousaria prognosticar nada de bom. Essa falta de percepção intuitiva que têm hoje os ricos ou quase ricos vai construindo cada vez mais uma segregação dentro do espaço urbano; na verdade, a tendência é, cada vez mais, dentro do tecido urbano, para os chamados condomínios fechados, que são tentativas de privatizar o que é público. Ou seja, a partir da cerca do condomínio, constitui-se um tipo de autoridade que não é mais pública, mas é autoridade do condomínio. No mínimo, se reduz e se restringe o direito de livre circulação porque, obviamente, há um ponto de passagem para entrar ou sair do condomínio. Se fosse só o condomínio seria pouco, mas há essa outra coisa espantosa que é o centro comercial. Eu não gosto de usar a expressão shopping center porque tento preservar ainda o idioma ibérico. $\mathrm{O}$ chamado centro comercial é um espaço de segregação muito mais radical que um condomínio porque ele segrega eliminando toda e qualquer referência ao lugar: não há mais paisagem, não há mais dia e noite, controlam-se todos os fatores e se estabelece no âmbito do centro comercial uma autoridade "para-pública" de natureza privada que tem poderes por vezes surpreendentes. Na verdade, esse 
movimento de segregação pode gerar também, em um processo que se projeta no tempo, um tipo de juventude que se cria dentro do espaço segregado. Para esse grupo, o que está fora do condomínio é estrangeiro. Então a convivência vai sendo destruída nesse processo de segregação em que estamos matando a praça pública. Acho que existe, por conseguinte, dentro do tecido urbano uma tendência preocupante

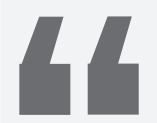

0 processo de privatização é muito mais avançado do que sugere a simples transferência de algumas empresas produtivas do setor público para o setor privado. $\mathrm{Na}$ verdade, 0 que está acontecendo é que o mundo da mercadoria está encurralando 0 mundo do bem público.

que, se não for revertida - insisto -, promete um mundo extremamente violento. A expressão dessa violência não está só nas questões ligadas à economia da droga, mas também no comportamento dos jovens filhos dos segregados que começam a se comportar fora do condomínio como se fossem de uma tribo que enfrenta outras tribos. Não sei se vocês acompanham, mas há um crescimento expressivo de conflitos entre tropas de jovens de condomínios versus condomínios, arena de luta, predominantemente nos espaços de lazer, de uma brutalidade sem referencial de cidadania ou de solidariedade. É uma degradação muito grande. O que está sendo destruído é a res publica, a coisa pública. O processo de privatização é muito mais avançado do que sugere a simples transferência de algumas empresas produtivas do setor público para o setor privado. Na verdade, o que está acontecendo é que o mundo da mercadoria está encurralando o mundo do bem público. É curioso, mas, de certa maneira, a pauta de discussão pós-Revolução Francesa tem grande atualidade no Brasil de hoje. Teríamos de repensar o que é público e o que é privado e, por meio de um pacto, que é, necessariamente, constitutivo de fronteiras. Caso contrário, a cidade vai se converter em alguma coisa que não tem nada a ver com a ideia de um espaço de cidadania interativa e cordial; vai se converter em um espaço rigorosamente recortado, onde a autoridade pública será um resíduo dentro desse mesmo espaço. Um dos poucos setores que gera emprego significativamente é a segurança privada associada a esse modo de organizar a cidade. Das projeções do subdesenvolvimento, nesse período de estagnação, é a mais atemorizante de todas. Neste momento não temos soluções pensadas, quer dizer, certamente todos nós diremos que uma política de ativa 
criação de emprego iria melhorar o cenário, da mesma forma que reforçando a capacidade de gasto do setor público seria possível fazer políticas públicas universais, incorporadoras etc. Mas os modos de operacionalizar essas políticas nós não os conhecemos. Queria chamar a atenção para mais um aspecto dessas coisas que estão ocorrendo por trás do lento crescimento e mostrando como o subdesenvolvimento é "dinâmico", ou, pelo menos, é inovador. Gostaria de fazer referência a algo que eu chamaria, à falta de outro nome, "padrões de articulação novos" entre o núcleo dito moderno da sociedade e a nossa periferia social. Vou apenas dar uma amostra dessas configurações. Vou falar daquele que talvez seja o mais importante de todos a meu juízo. Existe uma forma extremamente importante de estratégia de sobrevivência e de estratégia de fruição dos bens da modernidade, que é a geriatria do objeto. O núcleo moderno para tornar o durável não durável e toda a pedagogia do consumidor supõem que ele deixe de ser um colecionador e passe a ser um estuprador. Claro, o prazer não está em ter a coisa, está em usá-la pela primeira vez. É isso que explica o deságio brutal que tem o automóvel zero quilômetro quando sai da concessionária: na mesma calçada, perde $15 \%$ do seu valor. Poderíamos falar aqui do estuprador como o consumidor desejado pelo mercado global, mas o que quero mostrar é o movimento contrário que é feito, que é o de dar durabilidade ao que deveria ser finito. Chamo a atenção para os números que vou citar. $\mathrm{O}$ caminhão de estrada no Brasil tem dezoito anos, em média. Os tratores agrícolas brasileiros têm, em média, trinta anos. Sabem o que isso significa? Existem artesãos mecânicos que produzem as peças depois que elas pararam de ser fabricadas. Eles dão longevidade ao que deveria já ter sido sucateado. Na verdade, é a maneira pela qual se filtram para o espaço, vamos dizer, periférico do desenvolvimento os bens produzidos pela sociedade opulenta. Mas, ao mesmo tempo, ampliam o mercado para essa mesma economia opulenta, em uma simbiose extremamente original, porque nada mais parecido com o artesão medieval do que o mecânico de beira de estrada ou o lanterneiro que recupera uma carroceira ou o rapaz que sabe que engenharia reversa é uma expressão muito bonita, mas que o nosso operariado aprende a fazê-la desmontando as máquinas para procurar o defeito. Quantos são? Centenas de milhares. E o mais curioso é que, em uma operação bastante hipócrita, eles são chamados de microempresários. Então, temos uma estatística curiosíssima pela qual oitenta e tantos por 
cento das microempresas só tem o empregador, não tem empregado. $\mathrm{Na}$ verdade, é uma maneira muito curiosa pela qual se consegue converter, em muitos casos, aquele que fica desempregado e procura sobreviver na informalidade com um desses procedimentos em empresário de si próprio. $\mathrm{O}$ exemplo melhor que conheço é o do engenheiro que, desempregado, compra uma carroça de pipoca. Ele passa a ser empregado e empresário que emprega a si próprio. E as pessoas que o computam como gerador de emprego se esqueceram de que cada engenheiro que compra uma carroça de pipoca retira um popular do ofício de vender pipoca. Então, é como se o sistema todo estivesse fazendo uma expulsão das atividades mais interessantes da informalidade na área de pobreza, o que é confirmado com a queda sistêmica da renda média do informal. E a renda do formal, que também cai, está acompanhada de uma extensão do prazo médio de educação. Não é a educação que cria emprego, mas o mercado, extremamente restrito, é que dá preferência a quem tem mais anos de instrução. Por que estou dizendo isso? Porque de novo fico aflito ao colocarmos em uma camisa terminológica e em um padrão categorial fenômenos do subdesenvolvimento usando a linguagem que não é adequada. Artesão não é microempresário. O que é um informal? Não vou entrar por aí, mas essa é outra discussão, fundamental para entender a questão desta Mesa, que, como me disseram, era a das relações entre desenvolvimento e concentração de renda. Estou querendo chamar a atenção para que a progressão do subdesenvolvimento cria novos padrões de distribuição de renda. Reservei para o final o que considero o processo mais central e mais devastador de todos, que é a apropriação pelo Estado como um instrumento de captura de excedente e a relação entre renda financeira e riqueza mobiliária. Quando se analisa o Brasil deste ano, com 145 bilhões de juros de dívida pública, e quando se compara esse número com o programa de ajuda do Bolsa Família - que é o mais importante programa social que o Brasil faz, e que vai, no final deste ano, atingir oito milhões de 
famílias -, vê-se que esse programa, que tem importância muito grande nos grotões e nas regiões que estavam nos mapas do Márcio como as regiões mais problemáticas, só vai gastar $\mathrm{R} \$ 7$ bilhões, 1/20 dos juros da dívida pública. Devo a uma pesquisa feita pelo Márcio uma informação importantíssima. Trabalhando muito, lançando mão de uma série de hipóteses heroicas, Márcio conseguiu chegar à conclusão de que $80 \%$ desses juros de dívida pública beneficiam, em última instância, vinte mil famílias. Essa informação sugere o seguinte: o Estado nacional brasileiro realiza, pela equação fiscal, uma transferência de 120 bilhões para vinte mil famílias e 7 bilhões para oito milhões de famílias. $\mathrm{O}$ mais interessante é que oito milhões de famílias que recebem a Bolsa Família têm uma melhoria relativa no seu IDH, índice de desenvolvimento humano, não vamos desprezá-lo. Mas reparem a fantástica transferência que está sendo feita do miolo do corpo social para o topo da pirâmide, o que se expressa nos dados da repartição funcional a que Márcio fez referência. Por que essa apropriação pelo Estado de um instrumento de criação de riqueza? Porque o destino de uma parcela muito expressiva desses juros pagos é a aquisição de novos ativos financeiros derivados da emissão de títulos de dívida pública. Então, esse jogo é um jogo de acumulação absolutamente estéril, devastador, mas que deforma toda e qualquer hipótese de melhoria de distribuição de renda. Toda vez que ouço discurso sobre esse assunto fico dividido. Não vou fazer o discurso contra porque é evidente que, para cada família que recebe uma Bolsa Família, isso é importante. Mas, ao mesmo tempo, me sugere uma componente farisaica, espantosa, uma sociedade que festeja uma transferência brutal via tributária para essas vinte mil famílias e, ao mesmo tempo, distribui migalhas insignificantes para o corpo social. Queria finalmente fazer uma última referência. A nova forma do subdesenvolvimento é a destruição da república e a demolição da nação. Na verdade, as instituições estão sendo corroídas para tornar definitivamente crônico o quadro do desenvolvimento. Por quê? Sem a nação não há como enfrentar a premissa de uma melhor distribuição de renda; sem a nação não há como resolver a questão da inclusão social. Não creio que ninguém aqui deposite muita confiança na filantropia internacional. Certamente ninguém espera que haja, pelo neoliberalismo, uma abertura do mercado de trabalho mundial aos nossos excedentes de força de trabalho, nem que se faça qualquer sugestão, mesmo remota, de que o investimento do exterior 
é que irá dinamizar espontaneamente a periferia. Não é por aí. É pela nação ou não é pela nação. - $O$ que me angustia é que a nação está sendo desconstruída, e, ao mesmo tempo, no plano cultural, a idEia da república vai sendo devastada, porque o espaço da mercadoria vai atravessando, cada vez mais, os níveis que antes eram imaginados como níveis e espaços reservados à república. Se a república é encurralada e a nação, debilitada, podem nos colocar rigorosamente em uma situação de subdesenvolvimento, em que pressupostos fundamentais para enfrentar a questão não estão presentes. Paro por aqui. Não quis, de maneira nenhuma, transmitir uma visão pessimista: me deem um minuto para eu dizer por que sou otimista. Primeiro, porque acho que a linearidade na história é nota zero para toda e qualquer projeção de um cenário; é a forma de perder emprego. Só estava imaginando alguém que, no século XVI, projetasse um mundo em que a península Ibérica dominaria e teria uma colônia chamada Inglaterra. Mas, no século IX, quem projetasse a Inglaterra jamais poderia imaginar os Estados Unidos. Então, penso que toda e qualquer projeção tem o grande mérito de mostrar o que não vai ser a história. É evidente que este quadro de horror que estou projetando aqui não se vai configurar, porque não creio que sociedade alguma pratique suicídio ritual. É evidente que essa questão com a juventude, de uma segregação progressiva do espaço urbano, vai inspirar um movimento de repúdio. Por onde vem esse movimento, não me perguntem, porque não tenho bola de cristal. Mas tenho absoluta certeza disso: as projeções que fiz não se cumprirão, porque são demasiadamente absurdas. Entretanto, além desse discurso - que é um pouco mágico - de fé na capacidade do homem de se reencontrar e se recriar por dentro, porque não há lei de termodinâmica aplicável à história, não há entropia na história, eu gostaria de chamar a atenção para a existência de alguns dados de imensa importância e de grande potencialidade. Abri uma janela aqui quando falei do povo que cria formas de sobrevivência e, ao fazê-lo, move-se contra orientações que são determinantes. Ninguém tem dúvida de que a globalização caminha para esse consumidor perfeitamente idiota, que vive em um ambiente sem referência própria. A expressão máxima disso é o viajante, na Turquia, que quando entra em um shopping diz: "Que alívio, sintome em casa!” É verdade! Padronizou-se. Esses espaços climatizados são muito parecidos uns com os outros. Ao contrário, penso que aqueles que são colocados à margem desse processo subsistem, 
sobrevivem e criam de uma maneira muito original. Gosto muito de pensar o seguinte: só a pobreza é schumpeteriana, porque cria continuamente para sobreviver; ela tem uma imensa capacidade de desenvolver fórmulas de sobrevivência. Aliás, professor Sunkel - o senhor dedicou-se muito à questão ambiental -, eu diria que devemos uma medalha de honra ao mérito às populações pobres que reciclam tudo. Quem recicla é a favela! A favela é um espaço de reciclagem, ainda que seja proposto por certos discursos como um espaço de degradação. Não, ela recupera tudo. Aliás, uma informação: nós, brasileiros, por exemplo, somos campeões mundiais de reciclagem de alumínio. Não há uma latinha que fique por aí. Há tanta mão-de-obra disponível, que catam todas as latinhas e fazem reciclagem. Interessante. Este é o povo que combina a coisa schumpeteriana da inovação com uma coisa profundamente conservadora, porque não pode se dar ao luxo de abrir mão de nada do que sabe, do que tem e do que faz. Então, ele é a grande fronteira para manter a identidade. Há fatos muito interessantes que gosto de cifrar assim: enquanto a classe média "deleta" e "printa" para aproximar-se de Miami, não querendo usar os termos "imprimir" e "apagar" do velho Camões porque isso desqualifica, o povão faz o movimento contrário, escuta uma música em que há tonight e a transforma em "Melô do Tomate". Com isso, na verdade, ele é a grande reserva de identidade, no sentido mais profundo, de que a nossa sociedade dispõe. Não sou nada pessimista, porque temos um povo admirável. Em algum momento vamos descobrir que temos uma elite de muito má qualidade e a questão será resolvida em um grande encontro entre essas duas personagens. Mas, para isso, esperem a próxima edição do otimismo. Muito obrigado.

\section{Referências}

EARP, Fabio Sá. Carlos Lessa. Revista de Economia Contemporânea, Rio de Janeiro, v. 14, n. 2, p. 423-432, ago. 2010. Available from: $<$ http://www.scielo.br/scielo.php?script=sci_arttext\&pid=S1415-9848 2010000200008\&lng=en\&nrm=iso $>$. Access on: 11 Jun. 2020. https:// doi.org/10.1590/S1415-98482010000200008. 